\title{
Opt-Out Clause Is Not a Blank Check under Good Faith Lens
}

\section{Gabriel Soares dos Santos Machado}

Fundação Getúlio Vargas, Rio de Janeiro, Brazil

Email: gabrielmachado@mngm.com.br

How to cite this paper: dos Santos Machado, G. S. (2019). Opt-Out Clause Is Not a Blank Check under Good Faith Lens. Beijing Law Review, 10, 1066-1077. https://doi.org/10.4236/blr.2019.104057

Received: August 17, 2019

Accepted: September 22, 2019

Published: September 25, 2019

Copyright (c) 2019 by author(s) and Scientific Research Publishing Inc. This work is licensed under the Creative Commons Attribution International License (CC BY 4.0).

http://creativecommons.org/licenses/by/4.0/

\begin{abstract}
This paper is a case study of the final decision taken in the case $\mathrm{M} \& \mathrm{~F} \times \mathrm{Bank}$

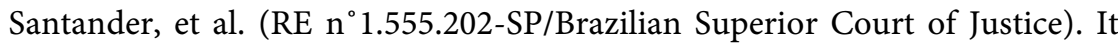
intends to answer two questions: whether it is reasonable to repudiate-as the Court did-the termination written clause of the contract signed by the Parties in the light of good-faith principle; and, assuming Bank Santander violated such principle when trying to terminate the contract, what the proper remedy due is. Our findings demonstrate that the Court did a good job by repudiating the termination written clause on good-faith grounds, but failed to stipulate a correct indemnity.
\end{abstract}

\section{Keywords}

Contract Breach, Good Faith, Damages

\section{Introduction}

In March 2017, the Brazilian Superior Court of Justice for federal law interpretation held that an opt-out clause is not a blank check to a party that wants to put an end to a contract. It ruled that this right must be performed in accordance with the general principle of good faith, which calls for a highly context-specific understanding of honesty and reasonableness. The case is M \& F $\times$ Bank Santander, et al. (hereinafter referred to as the Bank) ${ }^{1}$. The Bank contracted M \& F to collect debts on its behalf for a fee. In the wake of such a demand, M \& F had to invest around 100,000 USD in their business in order to cover the demand created. During the contract, the Bank increased their demand for M \& F services several times, based on the outstanding services levels $\mathrm{M} \& \mathrm{~F}$ had been rendering to the Bank. However, after 11 months of providing valuable services, $M$

${ }^{1}$ REsp. $n^{\circ}$ 1.555.202-SP (Brazilian Superior Court of Justice-STJ). 
\& F faced the Bank's decision to opt out the contract without any reasonable excuse amid preceding requirements to keep investing and pushing the business.

Although the Bank had exercised their right to opt out based on a contractual provision-which granted both parties the right to terminate the contract any time, provided that the other party should be informed of such an intent five days prior to the intended final term - the court held that the Bank had behaved in contradictory terms, against, therefore, good faith. After a comprehensive analysis of the case, the court concluded the Bank not only 1) misled M \& F to believe that the contract would have a longer duration, but also 2) terminated the contract without rendering enough time to the other party to recover the investments made, as quoted in the Brazilian Civil Code ${ }^{2}$ (Rose, 2012). In fact, two intricate issues arise from this decision. First, whether it is reasonable to repudiate a termination written clause that stipulated the bilateral right to opt out the contract by just sending a five-day-notification in advance. Second, what the proper remedy, assuming that the way the Bank had invoked such a termination provision was deemed unlawful.

In Part 2, I provide the main information regarding the case study. In accordance to such a decision under analysis, I argue in Part 3 that the duty of acting in good-faith-which is a matter of law in Brazil-is enough to refrain the Bank from taking advantages of the vulnerabilities created by the sequential character of the contractual performance. Given that they have offered hints that the contract would be in force for a longer period, their abrupt withdrawal is a measure equal to the breakage of the contract. Although the opt-out clause of the governing contract is legally valid, its use was not an option under those contingences. Part 4 presents the legal framing of the conduct carried out by Bank Santander. I will weigh whether article 473 (and its sole paragraph) is appropriate to rule this case and challenge the findings, in this regard, pronounced in the decision. In the very Part 4, I also explain what should be the extent of the indemnity and present the contributions of law and economics doctrine to such a stipulation, in the light of the Brazilian Civil Code. Part 5 presents the findings with analysis.

\section{The Case}

In this case, a claim for damages was filed by a collection company ( $\mathrm{M}$ \& F), based on the argument that they entered into a contract with the defendants (Bank) in order to provide debt recovery services, but the Bank breached it. The company reported that these services were provided in an exemplary manner and the results achieved in performing the contract charges were above the expectations. Additionally, the plaintiff stated that they made "massive

"Article 473. Unilateral termination, in the cases in which the law expressly or implicitly permits it, is made by notice given to the other party. Sole paragraph. If, however, given the nature of the contract, one of the parties has made considerable investments for its performance, unilateral notice of termination will only produce effect after a period of time compatible with the nature and extent of the investments has run." 
investments", as follows: the acquisition of a software valued at over $\mathrm{R} \$ 100,000$, the relocation of their headquarter to a larger location to accommodate new service providers hired to meet the growing demand, and a variety of other investments made solely in anticipation of the success of the newly opened contractual relationship. However, in less than a year after signing such an open-ended contract, $M \& F$ received a notice from the Bank stating that they would terminate the contract, in the light of a contract clause that granted them this right since they provide a five days prior written notice. Despite M \& F's efforts, the contract was terminated on the grounds that the relationship no longer covered the economic interests of financial institutions (the Bank).

Although the Trial Court had upheld the indemnity claim, the Court of Appeals overturned the prior decision arguing, "if the contract was freely signed between the parties, the pacta sunt servanda rule prevails, as each of the parties must bear the responsibility assumed in the agreement of wills". In turn, the Justice Luis Felipe Salomão, from Brazilian Superior Court of Justice, agreed that the wrongdoing that gives rise to contractual liability is to be understood less narrowly, beyond the concept of "illegality", reaching cases the absence of good faith occur. Furthermore, the Minister concluded the defendants acted in flagrant contradictory behavior by requiring investments necessary to provide the services, consistent with the size of the undertakings, which the applicants would cope with, and after 11 months, without any legally relevant justification, unilaterally terminated the contract. In accordance with Justice Salomão, "It is undisputed that there was no dishonorable conduct of $\mathrm{M} \& \mathrm{~F}$, either in the conclusion or execution of the contract, which, added to the progressive and constant increase of the services provided given the growing demand, gave the authors the legitimate impression that the agreement would still endure for a reasonable time".

Justice Salomão also argued that "The existence of the contractual clause providing the possibility of unmotivated termination by any of the contractors is not, in itself, relevant to dismiss and justify the unlawful termination of a contract that was being satisfactorily fulfilled, with results above reached by the contracted party. (...) What the legal system imposes is a proper unilateral termination, is the observance of good faith even at the moment of breaking the pact, especially when contrary to the interests of one of the parties". Thus, the Justice restored the first decision of the case that upheld the claims of the plaintiff, and convicted the defendants to pay reliance damages to $\mathrm{M} \& \mathrm{~F}$.

\section{Good Faith vs. Contract Provisions}

As for the conclusion to repudiate the use of the opt-out clause in reference to the circumstances the Bank called it forth, it seems that the Court has taken the right path, (Rose, 2012) as per the article $422^{3}$ of the Brazilian Civil Code. The "Art. 422. The contracting parties are bound to observe the principles of probity and good faith, both in entering into the contract and in its performance." 
notably known general duty of good faith and fair dealing is an imposed requirement on the parties in contractual relationship, which extends to the formation and performance of a contract and includes the notion of abuse of contractual rights. For this analysis, I will keep the focus on both moments: formation and performance. For a start, it is noteworthy that the right to opt out, as stated in the contract signed by the parties, is virtually legal. Such a provision is clear to grant the right of termination to any party by providing to the other party a 5-day-written termination notice. This clause cannot be deemed deceptive, even because the Brazilian Civil Code contemplates such a right ${ }^{4}$ (Rose, 2012). Furthermore, there is no apparently failure to disclose something in the negotiations leading up to the signing of the contract in this case. From the negotiations to the moment of the contract signing, either party seems not to have taken deliberate advantage of an oversight by the contract partner concerning any of its rights involved. Up to that moment, there were two companies deliberating on matters that they were clearly skilled and that they probably confronted each other with a natural wariness.

However, a significant interpretive question arises from the litigation related to the opt-out clause. As Posner says, the obvious but not the only reason, besides clumsiness in the use of words, is that contractual performance generally occurs over time rather than being complete at the instant contract is signed (Posner, 2004). As in almost all contracts, M \& F and Bank Santander written provisions aimed at regulating the future, and interpretative problems are bound to arise since the future is simply unpredictable ${ }^{5}$ (Resnik, 1986). Uncertainty may enter the picture either at first level-what to do-or at the second level-how much information to collect before deciding what to do-(Vermeule, 2013). Perfect foresight at the time of the contract signing would have been infinitely costly. It would carry a great-unintended cost, squandering many of the benefits of signing the contract without arising the party's suspicion that "he is foreseeing litigation and angling for an advantage in it" (Posner, 2014). Moreover, gathering more information could possibly cost the timing to contract in the light of Bank Santander needs. Thus, it sounds clear that when the Parties decided to bind themselves with this contractual provision, they did not intend to cover a contingency different from an opt-out under ordinary conditions.

Since there was no basis on which to form any calculable probability whatever of what really was about to happen in this case, notably regarding the very specific way Bank Santander called the opt-out clause for, it is mandatory to take into account the performances of the Parties. The performances usually shed enough light to define whether such a clause is able to regulate an equitable termination under specific conditions. In this case, as the performance unfolded, circumstances changed unforeseeably; the explicit terms of the contract became

\footnotetext{
4"Article. 473. Unilateral termination, in the cases in which the law expressly or implicitly permits it, is made by notice to other party."

5"If we had complete foreknowledge, individual decision theory would need only one principle, namely, make the right decision.”
} 
progressively less apt to the governance of this specific portion of the parties' relationship; and the role of implied conditions-thus, the scope and bite of the good-faith doctrine-grew (Posner, 1991). The opt-out clause ruled a very particular situation, which does not match the features that were found in the specific contingency that Bank Santander decided to bring it about. Actually, the performance of Bank Santander indicated that they had no reason to terminate the contract. At the time the Bank sent a termination notice to $\mathrm{M} \& \mathrm{~F}$, the parties were in a cooperative venture as a measure of $\operatorname{trust}^{6}$ (Cross, 2002).

The evidences in the lawsuit showed that the Bank had increased the amount of services under the contract signalizing they would go further on this task. On the one hand, the Bank demanded investments in a new software, work force and facilities to meet their escalating needs. On the other hand, M \& F incurred in all these sunk costs ${ }^{7}$ (Hermalin, Katz, \& Craswell, 2007) to cover the specific demand created by the Bank, believing these investments would not be in vain. Therefore, given that the Bank asked M \& F to keep investing all along the contract duration to cover their escalating demand for the services, and, suddenly, got out of the contract, it is adequate to conclude that they misled $\mathrm{M} \& \mathrm{~F}$ about its (their) intention to terminate the agreement prematurely. Boilerplate assertions-as pacta sunt servanda-are no longer individually efficient under the Brazilian Civil Code good faith provisions (Rose, 2012) (articles $113^{8}$ and 422). Before enforcing the opt-out clause ${ }^{9}$, the Bank should have taken into account that their conduct were abusive, namely, contradictory with their own past behavior and contradictory with the legitimate expectations they had created in favor of $M \& F$.

It is straightforward that M \& F would not voluntarily place themselves at the mercy of the Bank. So it is reasonable to infer that had the parties thought openly about the possibility of withdrawal under such contingencies, $M \& F$ would have forbidden it expressly. Although the contract fails to address this thought in an explicit sense, the article 422 of Brazilian Civil Code covers this contingency by disallowing all the parties of any contract to behave in contradictory terms ${ }^{10}$ (Aguiar Jr., 2011). The principle of Verwirkung ${ }^{11}$ (the principle which forbids a party to contradict himself to the detriment of the other party, or coherence in

\footnotetext{
"Relational deals are sometimes captured in formal contracts that depend not on the parties' enforcement of all legal entitlements but on flexible adjustments to maintain the ongoing business relationship."

"Even before they meet, potential contracting parties make a number of economic decisions that influence the possible gains from the future. (...) Some decisions create positive and negative externalities, and others entail relational investments that are vulnerable to holdup."

"Article 113. Juridical transactions shall be interpreted in conformity with good faith and the practice of the place in which they are made."

"“Article 187. The holder of a right also commits an illicit act if, in exercizing it, he manifestly exceeds the limits imposed by its economic or social purpose, by good faith or by good conduct."

${ }^{10}$ In this sense, Ruy Rosado de Aguiar Júnior, a former Justice of Brazilian Superior Court, has stated that the will to terminate a contract shall attend good faith, so that the request to terminate cannot be characterized as abusive.

${ }^{11}$ See the constructions around the adage non venire contra factum proprium in the analysis of (Houtcieff, 2001, Wieling, 1994, Shereiber, 2007).
} 
contractual matters) is not expressly provided for in the law, but has emerged from the analysis of case law and mainly of articles 113 and 422 of Brazilian Civil Code. This principle inflicts that coherence is an obligation attached to the good-faith duty, and since the Bank has not observed it, they incurred in a breach. Such an interpretation is even more convenient to a long-term-contract analyses-as the contract signed by the parties was-and it imposes the necessity of appropriate regard for the other party's interest. Stated differently, it allocates the risk as the parties could be expected to have done had they negotiated over the issue (Posner, 2009). After all, one of the five distinct economic functions of contract law is to prevent opportunism toward the contracting parties (Posner, 2014).

\section{The Indemnity Legal Framing}

Steven Shavell offered a bundle of explanations for the incompleteness of contracts $^{12}$ (Shavell, 2006). Along with the high costs to complete the contract, there is a likelihood that the Parties (or M \& F, at least) have relied on our legal regime, under which parties are able to commit breach and pay damages, to serve as a substitute for the specific contingency that is discussed on this lawsuit. At this point, the reason that underlies their decision of keeping the contract incomplete does not have a great relevance, but the remedy the law provides does. With respect to the learned judge (Luiz Felipe Salomão), I take the view that he has not approached this case from the correct angle concerned the legal framing set forth in his final decision. He stated that article $473^{13}$ (Rose, 2012) of the Brazilian Civil Code is indisputably the appropriate piece of law to regulate the case and, in fact, he took this article wording to evaluate the indemnity Bank Santander should pay to M \& F. In my opinion, this approach is untenable. Article 473 cannot rule the effects of a breach that led the contract to its end, but only the performance close to the ending. The timing to call this provision for is when the contract is in full force. It is a tool to prevent losses by subsidizing the party that decides to terminate the contract in an upright manner. In other words, this article sets a responsible pattern of behavior to terminate a contract, outlawing other forms of doing so. It regulates the performance of the party during the critical moment when it decides to bring the contract to an early end (considering the contract has a specific duration length) or simply terminates the contract (when the contract has an indefinite duration). However, if the performance is no longer in progress-as M \& F $\times$ Bank Santander, et al. contract is-the importance of article 473 to the case is not even secondary.

12“a) If a contingency is unlikely, the effort might not be worthwhile; b) Many contingencies are hard for a court to verify, so there will be difficult to confirm their occurrence; c) It may be rational for parties not to take pains to include many contingent provisions; $d$ ) The legal regime serves as an implicit substitute for contingent provisions; and e) Costs to completely detail a contract."

${ }^{13}$ "Article 473. Unilateral termination, in the cases in which the law expressly or implicitly permits it, is made by notice given to the other party. Sole paragraph. If, however, given the nature of the contract, one of the parties has made considerable investments for its performance, unilateral notice of termination will only produce effect after a period of time compatible with the nature and extent of the investments has run." 
In the previous Section 3, I stressed that the final ruling, by pronouncing that Bank Santander had breached the contract, correctly addressed the issue in the light of the duty of good faith. As the Brazilian Justice Luiz Edson Facchin states, the violation of the principle of good faith is a typical format of contractual default (Fachin, 2011). Hence, the issue comes not to article 473 of the Brazilian Civil Code, but to article 475 . Every time a breach of contract takes place, such a provision must guide the judge conclusions ${ }^{14}$ (Gonçalves, 2015), unless the parties had agreed on liquidated damages. The wording of article 475 is straightforward: "A party injured by non-performance (...) has the right to indemnification for losses and damages"15 (Shavell, 2006). This article does not take into account any agreement to terminate, as article 473 does. As a matter of fact, it copes with the aftermath of a breach (and not with the way to perform a contract). I mean, exactly what is at stake in the case M \& F $\times$ Sank Santander. It is clear that the Bank could have rightfully terminated the contract. But to do so, they had to firstly observe the good faith (article 422) - not acting in contradictory terms-and, then, the extent of the clause that stipulates a prior written notice (which is per se a valid provision). Conversely, the Bank decided not to behave in good faith, attracting to them the risks of the (bad) choice undertaken, namely, contract breakage (and not contract termination).

In case of breach, the remedy is confined on article 475 of the Brazilian Civil Code. This straight legal framing has to be respected; otherwise, it would be useless to keep considering insofar that "contract law is still an essential institution for an efficient market" (Cross, 2002). Before getting to the indemnity, it is worth noting that specific performance was not an option in this case. Although article 475 of the Brazilian Civil Code also allows the injured party to demand performance, it was not preferable in this deal, given its relational treatment and $\mathrm{M} \& \mathrm{~F}$ vulnerable position. There was a false symmetry between contractors and M \& F could become a prey ${ }^{16}$. Besides, the Bank Santander have explicitly demonstrated their willingness not to keep the contract in force, which is enough to disregard such an alternative ${ }^{17}$ (Farias \& Rosenvald, 2016). At last, as Shavell has stated, expectation damages are jointly superior to specific performance for production contracts (Shavell, 2006).

\footnotetext{
14"In any bilateral contract, a tacit resolution clause is presumed. It authorizes the aggrieved party by the breach to plead the dissolution of the contract, plus losses and damages."

${ }^{15}$ Article 475 of the Brazilian Civil Code also allows the injured party to demand performance. Nevertheless, it was not preferable in this deal, given the relational treatment and M \& F vulnerable position. There was a false symmetry between contractors. For instance, there was not a specific volume of services to be accomplished, which means that the Bank could reduce intentionally the demand and would not be obvious to say that the they were behaving opportunistically. It is worth noting that, in this regard, Shavell has exhaustively explained that expectation damages is jointly superior to specific performance for production contracts

${ }^{16}$ For instance, the contract did not ruled the specific volume of services to be accomplished, which means that the Bank could reduce intentionally the demand and would not be obvious to say that the they were behaving opportunistically.

${ }^{17}$ From the standpoint of key local practitioners, the good faith principle does not work as a basis for constraining one of the contracting parties to remain in the contract, frustrating their will of withdrawal.
} 
In reference to the indemnity, the Court ruled that the Bank should pay to $M$ \& F the whole amount of money this Party had lost by investing in this contract, in the light of the sole paragraph of the article 473 of the Brazilian Civil Code. They asserted that, in order to calculate such amount due, it is essential to consider the period of 6 months of the contract duration as sufficient for the absorption of such losses. Stated differently, the Court awarded damages to place the victim of the breach in the position they would have been if they had never contracted with the Bank. In addition, the Court expressly denied the right to recover damages based on the value of expectation damages (the civil law tradition refers to those damages as lucrumcessans). As stated before, there is a legal framing problem in this decision, which was determinant to lead to a distortion in the findings of a legally adequate and economically efficient indemnity. The starting point will be the very legal framing. I will set the reasons why article 475 of the Brazilian Civil Code should regulate the Bank misconduct, instead of article 473. In sum, the article (475) states that, in case of breach, the aggrieved party is entitled to recover "losses and damages".

To better understand the extent of this expression ("losses and damages"), we must refer to article $402^{18}$ (Rose, 2012) of the Brazilian Civil Code. According to the previous legal provision, an aggrieved party is entitled to recover what he effectively lost and what he reasonably ${ }^{19}$ (Coase, 1960) failed to yield. In other words, the breaching party should be liable for the full cost of repairing the aggrieved one. As Gustavo Tepedino states, "losses and damages" include what has been lost and what the party reasonably failed to profit (Tepedino, 2007). Furthermore, he explains that such adverb (reasonably) means that the creditor should profit what good sense says he would gain, by performing the contraction on its ordinary sense. In the wake of that approach, it is taken for granted that $\mathrm{M}$ \& F have the right not only to recover the amount they lost by investing in this contract. But also what they reasonably failed to profit. On the one hand, the economic length of the contract, the investments the Bank demanded to be done, and the increasing volume of services requested should guide the calculations of the profits $M \& F$ failed to realize. On the other hand, $M \& F$ shall recover all the expenses they incurred to perform the contract. I mean, the immediate decrease in $\mathrm{M} \& \mathrm{~F}$ assets.

When I said in Part III that after the breach and dissolution of the contract, the article 473 does not even have a secondary importance, it was precisely because this provision cannot be used neither to rule the case-as the Court did-nor to work as a parameter-as the Court also did-to find the effectively losses to be recovered. Put differently, that provision fits neither to rule the ex-

\footnotetext{
18“Art. 402. Except where otherwise expressly provided for by law, the losses and damages owed to the creditor cover, in addition to what he effectively lost, that which he reasonably failed to profit." ${ }^{19}$ Coase made an important alert about the word "reasonably": "The courts do not always refer very clearly to the economic problem posed by the cases brought before them but it seems probable that in the interpretation of words and phrases like 'reasonable' or 'common or ordinary use' there is some recognition, perhaps largely unconscious and certainly not very explicit, of economic aspects of the questions at issue".
} 
tent of the indemnity, nor to parameterize the way the indemnity shall be stipulated. Remember: the Bank breached the contract! Besides, M \& F could not mitigate the loss they suffered since no action or omission could indicate the Bank decision to breach it. All things considered, the right way to set the case demands from the interpreter to go under articles 475 and 402 of the Brazilian Civil Code which grants to the injured party, with a material breach of the contract, the right to seek monetary damages to cover his losses.

Apart from the legal framing, I will assess the economic (in) efficiency of the decision. However, firstly, it is noteworthy that, amid a bundle of statements, the Justice briefly mentioned a paper (Santolim, 2013) written by a Brazilian lawyer-about Robert Cooter and Thomas Ulen studies on Law \& Economics-to back up his findings about the extent of the indemnity. The argument was that the Court should discourage overreliance by limiting recoverable damages. $\mathrm{Al}$ though the argument in itself is totally right, it does not match the case contingencies again. All the investments $M \&$ F performed were in favor of bringing about an escalating demand created exclusively by the Bank. Moreover, there are evidences that the Bank required large investments to meet their high quality standards. It is so difficult to dispute such an idea that the very Court ruled the Bank misled M \& F about their intention to terminate the agreement prematurely, based on the argument they behaved against the legitimate expectations they had created in favor of M \& F. Hence, there is no ground to believe that M \& F over relied in this case.

Assuming that there was a breach and the optimal reliance $\mathrm{M} \& \mathrm{~F}$ deserved to the performance to this contract, an economic efficient approach does encourages the recovery of the losses and the amount reasonably expected to gain from performance. Cooter e Ulen said, "Perfect expectation damages restore the promise to the position that he or she would have enjoyed if the promise had been kept". They also said "(...) perfect expectation damages elicit efficient commitment from the promisor to perform" (Cooter \& Ulen, 2007). In the light of these statements, I argue: had the Bank had kept the promise, M \& F would have either incurred in losses derived from an abrupt termination of the contract or failed to profit from this contract. The answer is no, under the lens of the evidences put before the bars. Perfect expectation damages ${ }^{20}$ (Shavell, 2006) induce efficient commitment to performance and breach. Efficient commitment maximizes the surplus from the contract, which the parties can divide between them. Consequently, both parties to a contract benefit from having perfect expectation

\footnotetext{
${ }^{20}$ To a better understanding upon non-perfect expectation damages, Shavell says: "Yet, as many observers have noted, the expectation damages measure as it is actually applied tends not to be fully compensatory and may leave the victim of the breach substantially worse off than he would have been had there been performance. The reason given for believing the expectation measure often to be under compensatory include the following: First, courts are reluctant to credit hard-to-measure components of loss as damages. Hence, lost profits and idiosyncratic losses due to breach are likely to be inadequately compensated or neglected. Second, courts are inclined to limit damages to those that could have been reasonably foreseen at the time the contract was made; courts frequently do not redress consequential losses. Third, damages tend not to reflect the considerable delays that victims of breach may suffer. Fourth, legal costs are not compensated".
} 
damages as the remedy for breach, rather than having as alternative remedy (Cooter \& Ulen, 2007). The alternative remedy held by the Court opposes such an economic logic. Actually, it is an incentive to the Bank to keep capitalizing on opportunistic breakages, even though their behavior was not Pareto superior.

\section{Findings with Analysis}

Interpretation first focuses on the normal, accepted meaning of the words used by the parties. It is the starting point and the primary source of meaning. However, in the case M \& F vs. Bank Santander, et al., it is difficult-not to say impossible-to infer that the wording of the opt-out clause was able to rule all circumstances that one player decides to give it up. But even if we overcome the uncertainty about the parties' intent and assume it was possible to infer that the opt-out clause-as stated-could cover the circumstance the Bank called it for, the general rule of good faith (article 421 of Brazilian Civil Code) connected to the parties' performance would impose to the Bank a different course of action. Good faith-and its connected duty of not acting in contradictory terms-is a part of any contract irrespective of the parties' actual intent. They cannot effectively agree to exclude such a term. The law's true purpose in such a firm imposition of standard term is not so much to ascertain what the parties reasonably must have intended, but to limit contractual autonomy in the interest of public police (Blum, 2013). Therefore, since good faith is part of every contract, when someone do not observe it, a breach occurs.

Under the lens of such perspectives, these are the findings arising from this case:

- Unless the context indicates otherwise, words used in a contract should be given their ordinary, general, or lay meaning;

- Standardized contractual clauses made available often appear unsatisfactory to protect some interests of private autonomy;

- If the parties intend to rule the possibility to opt-out in a wide variety of the circumstances, they shall specify at least the most tricky cases;

- When structuring the contract treatment of such a tricky circumstances to opt out, the parties shall observe that the conduct must show coherence to the performance of the parties and the good faith;

- Good faith is a supplementary term of any contract (in accordance to the Brazilian law) that cannot be excluded by agreement;

- The good faith duty disallow opportunistic behavior and contradictory course of action;

- The non-observance of the good faith duty lead to a contract breach;

- Every contract breach is subject to perfect expectation damages under Section 475 of the Brazilian Civil Code; and

- Perfect expectation damages induce efficient commitment to performance and breach.

\section{Conclusion}

During the performance of the contract, the circumstances changed and the 
opt-out provision outlined on the contract could not be argued to regulate the attempt to terminate the Bank took into effect. All along the contract duration, the Bank spurred M \& F to keep investing and be deeply committed to its provisions, as if the future was prodigious. Since the contract was incomplete to regulate a termination under such circumstances, the less-than-fully-specified obligations ought to be performed in a way that preserve the good faith (and the reasonable expectations) as a matter of law (article 421 of the Brazilian Civil Code). Notably, the Court's decision has recognized that the Bank did not observe such a legal duty and, therefore, broke the contract.

Assuming nobody sets up a business only to recover the amount of money invested and assuming that M \& F's high performance resulted in a legitimate expectation to make good profits out of this contract, the Court should have awarded perfect expectation damages to them, rather than reliance damages. All things being equal, it is very difficult to assume that the Bank would stop collecting their money or that the contract had become uneconomical overnight. Moreover, there is no evidence that the breach seems not to be committed to averting a larger loss. The Bank's previous steps would not be in favor of increasing the business, if they were not capitalizing on this. Thus, why should the Court shorten the damages amount?

In fact, even if the breach was reasonable, it would not be a ground for escaping liability (Cooter, 1985). The Brazilian Legal System contends almost all breaches by offering a straightforward remedy, granted on article 475 of the Civil Code. Diverting from the contract law guidelines and economic efficiency-as the Brazilian Superior Court did in this case-is risky (Coase, 1960) (Laudan, $2006)^{21,22}$. At the very least, improved awareness of the potential pitfalls of misleading contractors makes them leerier about trying their luck. Further, it facilitates contract negotiations and minimizes uncertainty. And then, the whole economic system wins.

\section{Conflicts of Interest}

The author declares no conflicts of interest regarding the publication of this paper.

\section{References}

Aguiar Júnior, R. R. (2011). Comentários ao novo código civil(Vol. VI, Tomo II). Rio de Janeio: Forense.

Blum, B. A. (2013). Contracts (6th ed.). New York: Wolters Kluwer.

Coase, R. H (1960). The Problem of Social Cost. The Journal of Law \& Economics, 3, 1-44. https://doi.org/10.1086/466560

Cooter, R. (1985). Unity in Tort, Contract, and Property: The Model of Precaution.

21"It would therefore seem desirable that courts should understand the economic consequences of their decisions and should, insofar as this is possible without creating too much uncertainty about legal position itself, take these consequences into account when making their decisions."

22“Public legitimacy, as much as justice, demands accuracy in veredicts." 
Berkeley, CA: Berkeley Law. https://doi.org/10.2307/3480463

Cooter, R., \& Ulen, T. (2007). Law \& Economics (5th ed.). Boston: Pearson.

Cross, F. B. (2002). Law and Economic Growth.

Fachin, L. E. (2011). Contratos e responsabilidade civil: Duas funcionalizações e seus traços. Revista dos Tribunais. Ano 100. Volume 903.

Farias, C. C., \& Rosenvald, N. (2016). Curso de direito civil: Contratos (Vol. 4, 6th ed.). Salvador: Juspodivm.

Hermalin, B. E., Katz, A. W., \& Craswell, R. (2007). Contract Law. In Handbook of Law and Economics (Volume 1, pp. 3-138). Amsterdam: Elsevier.

Houtcieff, D. (2001). Le principe de cohérence en matière contractuelle. Préf. H. Muir-Watt, PUAM.

Laudan, L. (2006). Truth, Error and Criminal Law: An Essay in Legal Epistemology (Cambridge Studies in Philosophy and Law). Cambridge: Cambridge University Press. https://doi.org/10.1017/CBO9780511617515

Posner, R. A. (1991). Market Street Associates Ltd. Partnership v. Frey. United States Court of Appeals, Seventh Circuit.

https://scholar.google.com/scholar case? case $=11586839497432327931 \& \mathrm{hl}=\mathrm{en} \& \mathrm{as} \quad \mathrm{sdt}=$ 6\&as vis $=1 \&$ oi $=$ scholarr

Posner, R. A. (2004). The Law and Economics of Contract Interpretation. Chicago, IL: University of Chicago Law School. https://doi.org/10.2139/ssrn.610983

Posner, R. A. (2009). Let Us Never Blame a Contract Breaker. Chicago, IL: University of Chicago Law School.

Posner, R. A. (2014). Economic Analysis of Law (9th ed.). New York: Aspen Publishers.

Resnik, M. D. (1986). Choices: An Introduction to Decision Theory. Minneapolis, MN: University of Minnesota.

Rose, L. (2012). The Brazilian Civil Code in English (2th ed.). Rio de Janeiro: Renovar.

Santolim, C. (2013). A proteção dos investimentos específicos na resilição unilateral do contrato e o risco moral: Uma análise do artigo 473, parágrafo único, do Código Civil. Revista Síntese: Direito empresarial, 35, 9-13.

Shavell, S. (2006). Is Breach of Contract Immoral https://doi.org/10.2139/ssrn.868592

Shavell, S. (2006). Specific Performance versus Damages for Breach of Contract: An Economic Analysis. Texas Law Review, 84, 831-876.

Shereiber, A. (2007). A proibição do comportamento contraditório. Tutela da confiança e venire contra factum proprium. Rio de Janeiro: Renovar.

Tepedino, G. et al. (2007). Código civil interpretado conforme a Constituição da República (Vol. I, 2th ed.). Rio de Janeiro: Renovar.

Vermeule, A. (2013). Rationally Arbitrary Decisions (in Administrative Law). Harvard Public Law Working Paper No. 13-24. https://doi.org/10.2139/ssrn.2239155

Wieling, H. J. (1994). Venire contra factum proprium e colpa verso se stesso, Translation to Italian from the Original Version in German, Venire contra factum proprium und Verschulden gegen sich selbst (1994), Rocco Favale, in Rassegna di Diritto Civile. 